Ю. А. Шепель

\title{
СЛОВООБРАЗОВАТЕЛЬНЫЙ РЯД КАК ОБЬЕКТ ИЗУЧЕНИЯ ЛЕКСИЧЕСКОГО СОСТАВА ЯЗЫКА
}

Шепель Ю. О. Словотвірний ряд як об’єкт вивчення лексичного складу мови.

У статті порушується питання щодо вивчення словотвірчого ряду як комплексної одиниці словотвірчого рівня та визначення його місця у вивченні лексичного складу мови.

Ключові слова: словотвірчий ряд, дериватологія, похідне слово, комплексні одиниці словотвору, ієрархія, словотвірчий формант.

Шепель Ю. А. Словообразовательный ряд как объект изучения лексического состава языка.

В статье рассматривается вопрос изучения словообразовательного ряда как комплексной единицы словообразовательного уровня и определения его места в изучении лексического состава языка.

Ключевые слова: словообразовательный ряд, дериватология, производное слово, комплексные единицы словообразования, иерархия, словообразовательный формант.

Shepel Yu. O. In the article the question of study of word-formation row rises as complex unit of wordformation level and determining his location in the study of lexical composition of language.

Key words: word-formation row, derivation, derivative, complex units of word-formation, hierarchy, word-formation formant. 
Современная теория словообразования отражает последовательную реализацию системного подхода к описанию языка, вскрывает организацию языковых единиц, их объединение в сложные словообразовательные единицы. Накоплен достаточно большой опыт в определении взаимосвязи между исходными единицами словообразовательной системы - производными словами и разными типами их объединений, комплексов.

Отечественные дериватологи в течение последних пятидесяти лет рассмотрели отдельные фрагменты словообразовательных подсистем различных частей речи как в границах диахронии, так и в пределах синхронии.

С середины 70-х годов и вплоть до конца XX ст. в центре внимания дериватологов пребывала основная единица словообразовательной системы - производное слово. Благодаря исследованиям И. И. Ковалика, В. С. Перебейнос, А. Н. Тихонова, Р. С. Манучаряна, Н. Ф. Клименко, Н. А. Янко-Триницкой, П. А. Соболевой, Е. А. Земской, И. С. Улуханова, В. В. Лопатина, Е. Л. Гинзбурга, И. В. Альтман, О. Г. Ревзиной, 3. М. Волоцкой, Т. М. Возного и др. актуальным стало изучение реальных объединений производных слов, а также словообразовательных полей производных слов. $\mathrm{K}$ таким объединениям можно отнести словообразовательные гнёзда и словообразовательные ряды. Словообразовательные гнезда изучены достаточно полно. Словообразовательный ряд как единица системы словообразования относится к наименее исследованным объектам, несмотря на то, что это понятие было введено в науку о словообразовании в 60-е годы прошлого столетия П. А. Соболевой. Она писала: «Словообразовательный ряд определяется как конечное множество словообразовательных структур, характеризующееся тождеством последнего деривационного шага» [6, с. 168; 5; 7]. Определение лаконичное и достаточно чёткое. Уже один этот факт делает изучение словообразовательного ряда не только важным, необходимым, но и перспективным звеном в исследовании системы деривации. Однако в дериватологии этой сложной единице не уделялось достаточного внимания. До сих пор не выявлены основные связи её с другими комплексными единицами языка. Прежде всего, не определено отношение ряда к словообразовательному типу, цепочке, гнезду, парадигме. Не описаны структурно-семантические особенности рядов, не разработана методика их анализа, а также проблематика исследования. Однако некоторые шаги в этом направлении сделаны. Исследования, поднимающие практические вопросы построения словообразовательных рядов, представлены легко обозримым количеством (работы П. А. Соболевой, А. Н. Тихонова, Е. С. Кубряковой, Е. Л. Гинзбурга, М. Д. Барченковой, Н. В. Емельяновой, Н. Е. Виленской, О. В. Глебовой, В. П. Кочеткова, 3. В. Семериковой, Ю. А. Шепеля). 
Вместе с тем, что представляет собой такая единица системы словообразования, как словообразовательный ряд, какова его роль в системе языка и в словообразовании как подсистеме языковой системы, в науке о языке нет ответа. Даже современные учебники и учебные пособия по словообразованию не дают сведений о словообразовательном ряде как единице словообразовательной системы языка. На наш взгляд, объяснить это можно тем, что комплексный подход к изучению словообразовательного ряда в полной мере в дериватологии ещё полностью не реализован.

Концепция системы словообразования, разработанная в своё время И. И. Коваликом $[1 ; 2 ; 3 ; 4]$, в настоящее время считается общепризнанной не только в украинской дериватологии, но в целом в славистике. Однако эта концепция не лишена слабых мест и требует уточнений. Понимание системности словообразования будет оставаться односторонним и неполным, если его не дополнить результатами внутриструктурной типологии, в основе которой лежат такие исходные деривационные единицы, как словообразовательная парадигма, словообразовательная цепочка, словообразовательное гнездо и словообразовательный ряд. Поэтому в современной дериватологии не теряет своей актуальности вопрос рассмотрения и изучения системного характера связей общеструктурной производной лексики, в частности вопрос формирования словообразовательного ряда, определения его места и роли в системе языка и в системе словообразования, в частности.

В современном языкознании имеют место два основных представления о системном устройстве словообразования: словообразовательная система как совокупность словообразовательных типов в их взаимодействии; (2) словообразовательная система как совокупность словообразовательных типов и словообразовательных гнёзд. В обоих случаях, в качестве базовой единицы принимается словообразовательный тип. Но адепты первой точки зрения, признавая словообразовательный тип в качестве базовой единицы, строят здание словообразования, исключительно опираясь на эту комплексную единицу. Вслед за словообразовательным типом в системе словообразования они выделяют более крупные единицы, такие как словообразовательная категория, словообразовательный разряд, словообразовательный класс, представляющие собой различные объединения и группировки словообразовательных типов (И. И. Ковалик, Б. Н. Головин, Г. С. Зенков, АГ-70 и др.). Приверженцы второй точки зрения словообразовательную систему представляют как сложное устройство, в основании которого тоже лежит словообразовательный тип. Однако в вершину всего здания словообразовательной системы они помещают словообразовательное гнездо - самую крупную единицу (И. В. Альтман, Е. Л. Гинзбург, В. А. Горпыныч, Е. С. Кубрякова, Е. А. Земская, П. А. Соболева, 
А. Н. Тихонов, В. В. Лопатин, И. С. Улуханов, В. С. Перебейнос, Н. Ф. Клименко, А. И. Кузнецова, 3. А. Харитончик, И. Б. Штерн др.).

Объединяет поборников первой и второй точек зрения признание словообразовательных гнёзд в качестве важнейшей единицы словообразовательной системы. Во всём остальном взгляды исследователей существенно расходятся.

Таким образом, современная дериватология систематизирует явления словообразования через исследование двух основных единиц словообразовательной системы - словообразовательных типов и словообразовательных гнёзд, которые отражают разные уровни абстракции языкового материала. Словообразовательный тип рассматривается как этап систематизации изолированных словообразовательных структур, как обобщённое и типизированное отношение между группами однородных по своей структуре и семантике парных образований - производящего и производного слов. Словообразовательное гнездо - понятие, необходимое для выявления деривационного механизма словообразовательной категории, установления фазисности словообразовательного процесса (ср. однофазисные - многофазисные деривационные цепочки).

При рассмотрении словообразовательных рядов принципиально важным представляется использование форманто-/ основоцентрического подхода. Как основоцентрический, так и формантоцентрический подходы предусматривают определение адекватной для них единицы классификации и описания деривационной системы. Ею, несомненно, будет единица, отражающая словообразовательную системную организацию. Системность в словообразовании базируется на многих разнонаправленных оппозициях. Одним из таких направлений являются словообразовательные ряды дериватов.

Таким образом, объектом изучения лексического состава языка может стать словообразовательный ряд, который рассматривается в словообразовании как один из способов упорядочивания / организации производных слов.

Актуальность такого способа отражения структурных словообразовательных связей основывается на том, что современная дериватология сознательно ориентируется на «максимальные» единицы словообразовательной системы, которые демонстрируют, с одной стороны, тождество используемого словообразовательного средства и регулярную соотносительность с исходными единицами, а с другой, - общность корня и регулярную равноудаленность на то или иное количество формальных операций.

Методология обращения к СР может основываться, прежде всего, на понимании словообразования как иерархически упорядоченной системы.

То есть, следует исходить из того, что сложное взаимодействие мотивирующих основ и аффиксов характеризуется определёнными 
структурно-семантическими закономерностями, которые носят системный характер и очерчивают семантику аффиксальных производных.

Опыт изучения СР при чтении курса по словообразованию в вузе показывает, что совокупность системных закономерностей этого взаимодействия, факторы, обусловливающие значение производного слова, предусматривают при рассмотрении рядов связь семантики аффиксального производного с конкретными семантическими характеристиками мотивирующих основ, а также значение аффиксов предыдущих ступеней деривации, однозначность / многозначность и закономерности их взаимодействия. Это позволяет в конечном итоге прогнозировать семантику разнотипных // однотипных образований, составляющих словообразовательные ряды // подряды.

При этом следует помнить, что единицы описания, поставленные в зависимость от выбора параметров релевантных признаков и характеризующие сторону изучаемого объекта (в частности СР), далеко не всегда могут претендовать на исчерпывающее и в силу этого адекватное отражение соответствующего уровня. И напротив, языковые единицы, которые констатируют тот или иной пласт системной организации языка и определяются характером структурных функциональных связей, представляют собой универсальную или, по крайней мере, оптимальную величину, наиболее полно соответствующую реляционному каркасу системы. Поэтому на словообразовательном уровне в качестве константных единиц обычно принято признавать элементы, которые

(1) представляют собой инвариантные единищь;

(2) удовлетворяют требованиям структурно-функциональной единицьь.

Итак, словообразовательные ряды (L=классы слов) представляют собой конечные множества слов, объединяемые тождественным аффиксом последнего деривационного шага.

Слова же, составляющие словообразовательные ряды, являются терминальными точками ветвей соответствующих гнёзд. Внутри словообразовательного ряда производные упорядочиваются своей деривационной историей, так как их образованию предшествуют разные С-цепочки.

Словообразовательные ряды распадаются на смысловые составляющие. Семантическая структура ряда состоит из лексикосемантических вариантов, представляющих собой подряд в одном из аффиксальных значений входящих в него слов.

Как и семантический вариант гнезда, лексико-семантический вариант ряда может реализоваться в одном или нескольких словах, составляющих этот ряд.

В отличие от семантического варианта гнезда, в семантическом варианте ряда всегда присутствует категориальная сема и выражается 
словообразовательное значение. Связующими элементами выступают полисемичные слова, в которых выражается какое-либо значение аффикса.

В противоположность плану выражения словообразовательной системы, в котором гнёзда и ряды упорядочены отличным друг от друга образом, в плане содержания они организованы одинаково. Так, на уровне словообразовательной формы гнёзда имеют иерархическое строение, а ряды - многосвязное. На уровне содержания структуры словообразовательных рядов относятся, как и структуры гнёзд, к одному классу - к классу многосвязных.

Словообразовательный ряд строится, как я уже отмечал ранее, по формантоцентрическому принципу. Это не позволяет ему входить в структуру словообразовательного гнезда, в отличие от других единиц словообразовательного уровня. Однако словообразовательные ряды и гнёзда обладают одинаковым строением. Они взаимосвязаны и взаимофункциональны.

В плане содержания словообразовательные ряды фиксируют значения, релевантные для словообразования, причем типы значений равноправные. В плане выражения различие в типе значения актуализируется. Если словообразовательное гнездо служит планом выражения для семантического поля, если гнезда автономны и строго упорядочены, концентрированы, то словообразовательные ряды реализуют словарно-категориальные значения, разрывая тем самым гнёда и распределяя их составляющие по единицам другого уровня - по частям речи.

Сходство строения гнёзд и рядов на уровне содержания и их различие на уровне словообразовательной формы выражается в сходстве и различии составляющих и связок. В плане содержания непосредственно составляющими рядов, как и гнёзд, являются лексико-семантические варианты, а связками - значения многозначных слов. Если в плане выражения гнёзда состоят из ветвей - парадигм, цепочек, то ряды - из слов. Ветви в гнёздах связаны основами, а составляющие рядов аффиксами. Стыки гнёзд и рядов распадаются на части, которые тоже упорядочиваются иерархически.

Словообразовательный ряд может состоять из одной словообразовательной пары или нескольких пар, у которых совпадают словообразовательные форманты.

В один словообразовательный ряд могут объединяться словообразовательные цепочки, имеющие производные с одним и тем же формантом. В этом случае словообразовательный ряд можно рассматривать как цепочки однокорневых слов, объединенные по общности форманта производного слова последнего деривационного шага.

Словообразовательный ряд можно рассматривать как некий архитип по отношению к конкретному словообразовательному типу (т.е. как иерархически упорядоченную систему подтипов в системе / структуре 
ряда). Производное слово характеризуется многомерностью семантического пространства, которое специфически актуализируется в границах словообразовательного типа и словообразовательного ряда, облегчая возможность образования и воспроизведения дериватов по аналогии. Одно инвариантное словообразовательное значение может характеризовать несколько словообразовательных типов, но только один словообразовательный ряд.

Поэтому при определении словообразовательного ряда следует говорить о тождестве словообразовательного значения, а при определении словообразовательного типа - о том семантическом рисунке, который является специфическим для каждого отдельно взятого типа. В отличие от словообразовательного ряда С-тип имеет нечёткие семантические границы, что обусловливается разными деривационными процессами (в том числе и полимотивацией), которые детерминируют синергетические явления в словообразовании.

Словообразовательный ряд - это парадигматический ряд. Это совокупность производных, которые объединяются на основе вариативноинвариантного принципа: инвариантная составляющая для ряда - это словообразовательный формант последнего деривационного шага, а вариативная составляющая - основа / корень мотивирующего слова. В этом отношении ряд уподобляется словообразовательной парадигме, типу, паре, цепочке и образует вместе с ними систему классификационных единиц словообразования. Такое понимание ряда подводит к выявлению центральных (прототипических) и периферийных семантических зон в границах одного ряда. Производное слово выступает как представитель словообразовательного типа и словообразовательного ряда как наиболее крупной единицы словообразовательной системы, что объединяет типы по линии форманта. Систематизирующая роль и качество словообразовательного ряда делают его единицей классификации.

Словообразовательные ряды в свою очередь являются составляющими более крупных единиц - макрорядов, каковы рассматриваются в качестве составляющих таких словообразовательных макроединиц, как аллигатуры и констелляции.

И в заключение отмечу, что словообразовательная система представляет собой упорядоченное множество единиц - констелляций, аллигатур, рядов и гнёзд, подрядов и подгнёзд, находящихся в отношении взаимосвязи и иерархии. Эта система, как и её составляющие, служит задаче упорядочения всего словарного состава языка.

Развитие словообразования осуществляется через словообразовательные гнёзда, а фиксация, сохранность лексики - через словообразовательные ряды. Словообразовательные ряды выполняют функцию фиксаторов слов в системе языка и словообразования, в частности. 
Единство словообразовательной системы осуществляется через взаимодействие рядов и гнёзд. Они как бы пронизывают друг друга. Ряды составляют скелет, каркас, на который нанизываются гнёзда.

\section{Поэтому изучение СР как КЕС крайне необходимо.}

\section{Литература}

1. Ковалик I. І. Вчення про словотвір / І. І. Ковалик. - Львів : Вид-во Львів. ун-ту, 1961. - Вип. 2. - 83 с.

2. Ковалик И. И. Вопросы словообразования имен существительных восточнославянских языков в сравнении с другими славянскими языками : автореф. дисс. на соискание уч. степени д-ра филол. наук : спец. 10.02.02 «Украинский язык» / И. И. Ковалик. - Львов, 1961. - 37 с.

3. Ковалик И. И. Некоторые вопросы славянского словообразования / И.И. Ковалик // IV Междун. съезд славистов : Материалы дискуссии. Проблемы славянского языкознания. - М., 1962. - Т. 2. C. $118-119$.

4. Ковалик I. І. Основні проблеми вчення про словотвір / I. І. Ковалик // Українська мова i література в школі. - 1970. - № 10. - С. 22 - 30.

5. Соболева П. А. Аппликативная грамматика и моделирование словообразования : автореф. дисс. на соискание уч. степени д-ра филол. наук : 10.677 «Теория языкознания» / П. А. Соболева. - М., 1970. - 60 с.

6. Соболева П. А. Моделирование словообразования / П. А. Соболева // Проблемы структурной лингвистики 1971. - М. : Наука, 1972. - С. 165 - 212.

7. Соболева П. А. Словообразовательная полисемия и омонимия / П. А. Соболева. - М. : Наука, 1980. -294 c.

Стаття надійшла до редакції 16.11 .2011 р. 